\title{
Kompetencje powiatów ziemskich w Polsce
}

\begin{abstract}
Iwona Koza*
Samorzad terytorialny to niezależny, autonomiczny organizm, o którego istocie przesądzaja jego podmiot, przedmiot oraz sprawowane zadania.

Samorzadność lokalna funkcjonuje, opierając się na zasadach subsydiarności, samodzielności, decentralizacji demokratycznej i wolności. Obecnie funkcjonujące w Europie systemy zależa od prowadzonej przez dane państwo polityki, istniejacych $w$ nim struktur administracyjnych i politycznych, uwarunkowań gospodarczych oraz zatożonych i przyjętych systemów kierowania. Za wzorzec administracji zdecentralizowanej może stużyć samorzad terytorialny we Francji, Wielkiej Brytanii czy w Niemczech.

Polski system samorządu terytorialnego ksztattuje się od siedmiu stuleci. Szczególne piętno wywarly na nim czasy rozbiorowe i perturbacje w zesztym stuleciu. Zręby obecnego systemu zostaty potożone dwadzieścia trzy lata temu. Konstrukcja powiatu nie spetnia jednak wymagań nowoczesnej administracji publicznej, jest przedmiotem uwag krytycznych, tym bardziej, że kolejne ekipy rzadzace odbieraja tym jednostkom samorzadowym kompetencje, pozbawiajac je tym samym sensu istnienia.

Wnioski z badania poruszanych wyżej kwestii oraz potencjalne rozwiazania moga być zaprezentowane na schematach blokowych wynikajacych z obserwacji zarówno tta historycznego, jak $i$ otoczenia geopolitycznego oraz obowiazujacego prawodawstwa. Wtaczyć tu również można konkluzje plynace z badania statystycznego obszarów spotecznego, gospodarczego, i finansowego. Treść niniejszego artykutu, ze względu na wymogi redakcyjne, nie będzie obejmować szczegótowego wnioskowania statystycznego, a stanowić będzie tylko odniesienie do konkluzji plynacych z badań analitycznych.

Korekta systemu powiatów ziemskich jest niezbędna. Warto prezentować koncepcje mogące wesprzeć procesy reform odnoszace się do tych jednostek samorzadowych, wśród których najkorzystniejszym pomystem wydaje sie korekta kompetencji tych jednostek samorzadowych. Potrzebne sa jednak dalsze, bardziej szczegótowe analizy sytuacji polskich powiatów ziemskich.
\end{abstract}

Słowa kluczowe: powiat ziemski, kompetencje jednostek samorządowych, governance.

Nadesłany: 6.08.2014 | Zaakceptowany do druku: 10.10.2014

\section{The Powers of Rural Districts in Poland}

Local government is an independent, autonomous body, which essentially prejudge its subject, object, and duties performed according to the principle of subsidiarity, autonomy, decentralization, democracy and freedom.

The existing systems in Europe depend conducted by the state policy in the existing administrative structures and political and economic conditions assumed and adopted management systems. A model of decentralized administration can serve local government in France, in the UK, or in Germany.

Polish system of local government is formed from seven centuries. Special stigma had on the partitioning and perturbation times in the last century. The foundations of the current system

* Dr Iwona Koza - Państwowa Wyższa Szkoła Zawodowa w Chełmie, Instytut Matematyki i Informatyki. Adres do korespondencji: Państwowa Wyższa Szkoła Zawodowa w Chełmie, Instytut Matematyki i Informatyki, 22-100 Chełm, ul. Pocztowa 54A, e-mail: ikoza@pwsz.chelm.pl. 
were laid twenty-two years ago. However, the construction of the districts does not meet the requirements of modern public administration, is subject to criticism, the more that subsequent governments take away their powers, thereby depriving them of the meaning of existence. The study addressed the above issues and possible solutions can be presented in block diagrams, which will be based on the observation of the historical background and the geopolitical environment and the existing legislation. Turn on here can also be conclusions derived from the survey areas of social, economic, and financial. Due to the limited length of this article, it will skip the detailed statistical analysis and will be only a reference to the conclusions of analytical tests.

Correction system of districts is essential. The best solution seems to be a correction of the competence of those local government units. Nevertheless, the need for further, are more detailed analysis of situation of Polish rural districts.

Keywords: rural district, the powers of local government units, governance.

Submitted: 6.08.2014 | Accepted: 10.10.2014

JEL: E62, E65, G28, H70, H71, H72, H76

\section{Wprowadzenie}

Samorządy terytorialne to jednostki o charakterze korporacyjnym wyposażone w osobowość prawną o charakterze publicznym i prywatnym. Jednostki te są niezbędne i fundamentalne dla społeczeństw, w pewnym stopniu warunkują ich byt.

Warunkiem niezbędnym i fundamentalnym dla każdego społeczeństwa jest stworzenie i utrzymywanie określonego ładu społecznego, umożliwiającego jego sprawne funkcjonowanie, w tym określenie reguł, zasad i kryteriów, które będą wyznaczały ten ład. Z powyższych powodów, obok organów państwowych, w obszarze życia publicznego funkcjonują organy samorządu terytorialnego (Dylewski, Filipiak i Gorzałczyńska-Koczkodaj, 2006; Kasiński, 2008).

Prawo obywateli do uczestniczenia w zarządzaniu sprawami publicznymi wchodzi w zakres demokratycznych zasad wspólnych dla wszystkich państw europejskich. Jest to możliwe przy założeniu istnienia społeczności lokalnych wyposażonych w organy decyzyjne, ukonstytuowane w sposób demokratyczny, korzystające z szerokiej autonomii w zakresie kompetencji, form wykonywania uprawnień oraz środków niezbędnych do realizacji zadań.

Autonomia - zgodnie z etymologią języków europejskich - jest substytucyjnym określeniem dla samorządności, niezawisłości, samostanowienia. W rzeczywistości samorządów terytorialnych powinno się to przekładać na wiarygodne prowadzenie spraw publicznych poprzez wyłonione w drodze wyborów organy dla dobra beneficjentów - mieszkańców danego obszaru stanowiących podmiot każdej wspólnoty lokalnej. Ustawodawstwo, zarówno ogólnoeuropejskie, jak i suwerenne stanowienie prawa w każdym państwie, wyznacza samorządom zadania obligatoryjne dopełniające w stosunku do zadań wykonywanych przez centralne organa władzy. Zabezpiecza ono również wykonywanie oraz finansowanie tych lokalnych zadań, a także sprawuje nadzór nad rzetelnością ich wypełniania (Dolnicki, 2003). Tymczasem kwestia zasady podziału kompetencji między państwo a samorząd jest stałym obszarem sporu.

W sferze samorządu terytorialnego widoczne są specyfika i unikalny charakter każdego państwa. Kolejne akapity niniejszego artykułu stanowią charakterystykę systemów samorządowych na naszym kontynencie. $\mathrm{Na}$ jej tle przedstawiona jest specyfika i kłopotliwe kwestie dotyczące polskich jednostek samorządu terytorialnego, zwłaszcza jeśli chodzi o problematykę finansowania ich zadań. Stanowi ona zarówno o poziomie obciążenia jednostek samorządowych - ponoszonych przez nie kosztach, jak i o wieloaspektowych konsekwencjach funkcjonowania takich, a nie innych rozwiązań prawno-finansowych, tzn. o efektach funkcjonowania polskich samorządów. Przedmiotem opracowania są powiaty ziemskie w Polsce, ponieważ ten szczebel samorządu i jego funkcjonowanie okazują się kumulować w sobie najwięcej kontrowersji. Okres badania, do którego 
odnoszą się wnioski przedstawione w dalszej części niniejszego artykułu, odnosi się do lat 2004-2013 i dotyczy wszystkich 314 powiatów ziemskich ${ }^{1}$.

Opierając się na powyższych spostrzeżeniach, warto podjąć dyskusję nad aktualnymi problemami rozwoju teorii i praktyki funkcjonowania polskich samorządów oraz wskazać odnośne obszary badawcze.

W omawianym kontekście można postawić hipotezę, że legislacja stanowiąca o wydatkach polskich powiatów ziemskich utrwala nieprawidłowości w funkcjonowaniu tych jednostek. W związku z tym warto zastanowić się nad korektami kompetencji polskich powiatów ziemskich. Warto, stosując odpowiednie narzędzia badawcze ${ }^{2}$, pozyskać wiedzę o tym, co w omawianej problematyce funkcjonuje nieprawidłowo i powinno być naprawione, zreformowane, jak i zasugerować program naprawczy, majaccy na celu przezwyciężenie zidentyfikowanych trudności i poprawę sytuacji oraz ocenę wprowadzonych zmian. Wnioski zostaną, na potrzeby niniejszego artykułu, skoncentrowane głównie na korekcie kompetencji polskich powiatów ziemskich.

\section{Zarys kompetencji samorządów terytorialnych w Europie}

Początków współczesnego samorządu terytorialnego należy upatrywać w przełomie umysłowym i politycznym epoki oświecenia. Ukształtowanie koncepcji praw naturalnych, przyznanie podmiotowości jednostce i akcentowanie roli rozumu ludzkiego szły w parze z modyfikacją systemu nauczania, rozwojem rynku prasowego i postulatami radykalnych przemian. Na gruncie idei rewolucji francuskiej zrodziły się trzy teorie samorządu terytorialnego:

- teoria naturalistyczna samorządu, której fundamentalna struktura wykształciła się we Francji;

- teoria państwowej samorządności, która powstała w Prusach;

- teoria polityczna samorzadu, która powstała w Wielkiej Brytanii, a w szczególności w Anglii.

W najwcześniejszej teorii samorządu teorii naturalistycznej - samorzad został przeciwstawiony państwu jako czynnik od niego niezależny. W ramach tej teorii wykształciła się wolność gminy wyprowadzona z naturalnego prawa komuny. Gmina jest więc starsza od państwa i to państwo od gminy wywodzi swe prawa. Państwo jest właściwie federacja gminy. Państwo istnieje dla gminy, gmina jest nietykalna dla państwa. Gmina załatwia sprawy niezmiennie wynikajace $z$ natury jednostki i ma własny nienaruszalny zakres działania. Nadzór nad samorzadem w tej teorii praktycznie nie istniał - zgodnie $\mathrm{z}$ twierdzeniem ,nikomu nic do tego, jak działa samorząd". Tej teorii zawdzięcza się podjęcie władzy komunalnej, tzw. czwartej władzy. Rozwijała się ona głównie we Francji. Od połowy XIX wieku zaczęto zauważać, że nie ma możliwości traktowania samorządu jako niezależnego bytu od innych władz, a prawo komunalne jest częścią prawa państwowego (Oates, 1999; Rajca, 2008).

Zgodnie $\mathrm{z}$ teorią państwowej samorządności, powstałą w Prusach, państwo samodzielnie wykonuje władzę poprzez swoje organy, ale może przekazać część swojej władzy społecznościom miejscowym, które są odrębnymi podmiotami prawnymi, wchodzącymi w stosunki prawne z państwem. Według tej teorii samorząd polega na wykonywaniu praw zwierzchnich odstąpionych przez państwo korporacjom samorządowym. Realizują one zadania na podstawie ustaw i w ich granicach, a ich organy pochodzą z demokratycznych wyborów i podlegają nadzorowi pod względem kryterium legalności. U podstaw teorii państwowej samorządności leży idea powołania lokalnego społeczeństwa terenowego do wykonywania administracji państwowej w terenie. Zakłada się, że państwo może wykonywać władzę bezpośrednio poprzez podległe mu organy. Część tej władzy może ono przekazać społeczeństwu miejscowemu, które stanowi odrębną osobę prawną, wchodzącą $\mathrm{w}$ stosunki prawne z państwem. Lokalna osoba prawna staje się podmiotem samorządu wówczas, gdy państwo upoważnia ją i zobowiązuje do realizacji określonej funkcji administracji państwowej. Nowoczesny samorząd terytorialny ukształtował się zatem wtedy, gdy stosunek władzy państwowej przestał być jednostronnym stosunkiem poddania się suwerenowi, a stał sie dwustronnym stosunkiem prawnym, zakładającym istnienie praw podmiotowych jednostek i ich zbiorowości.

Według teorii politycznej samorzadu nie jest on tworem prawnym, a jest tworem politycznym - samorzad to nie rozwiazanie prawne, ale określona myśl polityczna; 
istote samorządu terytorialnego stanowi udział obywateli w administracji publicznej oraz istnienie kolegialnych organów samorządowych. Dalsze prawidłowości zawarte w teorii politycznej głosza, że nie można wypracować stałych zasad i reguł funkcjonowania samorządu. $\mathrm{O}$ samorządzie można byłoby mówić, gdyby urzędnicy nie byli wynagradzani i nie byliby zależni od rządu. Niezależny samorząd powstanie dopiero wtedy, gdy stworzy się niezależność (Swianiewicz, 1997; Stępień, 2006).

Istotne znaczenie dla rozwoju teorii i praktyki samorządu miała francuska i pruska myśl teoretyczna, pod wpływem której samorząd terytorialny nabierał charakteru demokratycznego. Jego podstawą była idea udziału społeczeństwa w wykonywaniu administracji państwowej. Przenikła ona do ustaw poszczególnych krajów europejskich i już od końca XIX wieku upowszechniła się instytucja nowoczesnego samorządu terytorialnego, która do dnia dzisiejszego kształtuje system zarządu lokalnego w Europie (MacGregor Burns, 1979; Sanford, 2004; Maciejewski, 2006).

Obecnie - w konsekwencji przeobrażeń dziejowych - realizowane są różne koncepcje samorządu terytorialnego (Kleer, 2008).

\subsection{System francuski}

Samorząd terytorialny we Francji jest wzorcowym przykładem administracji zdecentralizowanej ${ }^{3}$. Regiony francuskie, utworzone po drugiej wojnie światowej dla celów administracji rządowej, w 1982 roku stały się jednostkami samorządu terytorialnego, nie uzyskały jednak żadnych uprawnień ustawodawczych. Francja stanowi tym samym przykład regionalizmu administracyjnego, który można przeciwstawić regionalizmowi politycznemu w sensie powszechnej autonomii regionalnej.

Współcześnie we Francji obowiązuje trójszczeblowa struktura samorządu lokalnego: gminy, departamenty oraz regiony. Posiadają one status wspólnot lokalnych albo terytorialnych. Do cech jednostek samorządowych należą odrębna osobowość prawna, istnienie na danym obszarze społeczności ukształtowanych historycznie, które charakteryzuje interes lokalny oraz wyłanianie rad lokalnych w wyborach powszechnych oraz bezpośrednich (Gremion, 2002).

Niezmiennie przez ostatnie dziesięciolecia, samorząd francuski aktywnie realizowa formułę administracji zdecentralizowanej.

\subsection{System brytyjski (anglosaski)}

Wielka Brytania to kraj tzw. klasycznego samorządu terytorialnego. Od czasów feudalnych Brytyjczycy niezmiennie przywiązują do słowa „samorząd” dużo większą wagę niż w innych krajach. Administracja terytorialna Wielkiej Brytanii, a zwłaszcza Anglii, jest od średniowiecza oparta na pełnym samorządzie terytorialnym (Łokucijewski, 1998). Z punktu widzenia Brytyjczyków samorząd oznacza sposób rzadzenia, gdzie obywatele biora udział we wszystkich kierunkach władzy państwowej, czy to w ustawodawstwie, administracji, czy w sądownictwie. Specyficzną cechą ustroju Wielkiej Brytanii jest brak konstytucji w znaczeniu formalnym - konstytucji spisanej. Zamiast niej o ustroju państwa informuje konstytucja w sensie materialnym, to znaczy ogół norm i zasad dotyczących wykonywania władzy. Kompetencje administracji lokalnej w Wielkiej Brytanii maja źródła w nastepujacych aktach prawnych: ustawach, prawodawstwie delegowanym, ustawodawstwie indywidualnym oraz regulaminach (Turpin, 1986; Wojnicki, 2003). W systemie anglosaskim całokształt administracji terytorialnej skupiony jest w rękach niezależnych od administracji rządowej różnorodnych organów samorządowych, wybieranych i odwoływanych przez ludność miejscową, wykonujących zadania powierzane $\mathrm{w}$ innych państwach administracji rządowej (Guziejewska, 2000; Rajca, 2007).

Samorząd brytyjski to modelowy przykład silnych samorządów z utrwaloną od wieków tradycją oraz wartą naśladowania pełną decentralizacją władzy lokalnej.

\subsection{System niemiecki}

Interesujacy przykład kształtowania samorządu terytorialnego jako podstawowej formuły decentralizacji administracji stanowią Niemcy (Palmowski 2002; Izdebski, 2006)

Niemiecka ustawa zasadnicza w pełni gwarantuje niezależność samorządu. Wszystkie jego szczeble działają samodzielnie i na własną odpowiedzialność. Organy rządowe mają dość ograniczoną możność wnikania w sferę spraw zastrzeżonych dla władz lokalnych. Te ostatnie mogą zresztą wystąpić na drogę sądową o ochronę swoich praw poprzez sądy administracyjne i Związkowy Trybunał Konstytucyjny. Konstytucja Niemiec stanowi, iż prawodawstwo 
komunalne należy do kompetencji poszczególnych krajów związkowych. W związku z tym, zasady działania samorządu lokalnego precyzują ustalenia zawarte w ustawach zasadniczych krajów związkowych Obejmują one zwyczajowo: istotę samorządu i jego zadania, strukturę samorządu i zarządzania, gospodarkę samorządu oraz nadzór nad jego działalnością (Appuhn, 2008).

\section{Współczesne systemy samorządu terytorialnego}

Współcześnie, w odniesieniu do polityki stosowanej na linii państwo-samorząd, najczęściej stosowane są: polityka neoliberalna oraz polityka postkeynesowska. W polityce finansowej i rozwiązaniach teoretycznych teorii neoliberalnej, która zyskała sobie ostatnio wielu zwolenników w krajach anglosaskich, we Francji i Niemczech, dominuje tzw. teoria neutralności. Polega ona na nieingerowaniu państwa w życie gospodarcze i oparciu systemu gospodarczego na prostych, jednolitych i niskich stawkach podatkowych. Mimo przyjęcia poglądów neoliberalnych przez wielu praktyków gospodarczych, polityki neoliberalnej nie stosuje się w praktyce większości państw w odniesieniu do gospodarki lokalnej, jak również i jednostki lokalne nie bazują na tej teorii w swojej praktyce zarządzania. Duża gama różnorodnych form i konstrukcji dotacji, subwencji, udziałów i innych form pomocy finansowej świadczy o stosowaniu przez państwo zdywersyfikowanych instrumentów interwencji finansowej w odniesieniu do gospodarki lokalnej. A zatem, niezależnie od czynionych deklaracji, w praktyce $\mathrm{w}$ odniesieniu do gospodarki lokalnej dominuje nie polityka neoliberalna, lecz polityka postkeynesowska. Świadczą o tym także stosowane różne formy subwencji i dotacji, z których wiele ma charakter przedmiotowy, ingerujący w działalność gospodarki lokalnej. Jako formy oddziaływania są także stosowane różne warunki przy udzielaniu pożyczek ze środków budżetu państwa albo przez różne fundusze i jednostki publiczne (Gajl, 1993).

Występujące na świecie systemy samorządu terytorialnego można klasyfikować, opierając się na następujących kryteriach (Ruśkowski, 1997; Kaczmarek, 2005):

- typ państwa;

- forma państwa;
- struktura podziału terytorialnego kraju;

- zakres i jakość decentralizacji finansowej.

Tradycyjnie rozróżnia się dwa typy państwa: socjalistyczne i kapitalistyczne. Zarówno zasady ustrojowe, jak i systemy finansów lokalnych obydwu typów tych państw są zasadniczo odmienne ${ }^{4}$. Zasada oddzielenia samorządu terytorialnego od państwa, jako odrębnych podmiotów publiczno-prawnych, z jej konsekwencjami ustrojowymi, majątkowymi i prawnymi, sytuuje finanse lokalne w państwach kapitalistycznych w zasadniczo odmiennej sytuacji od lokalnych finansów rad narodowych w państwach socjalistycznych, w których obowiązywała jedność mienia ogólnonarodowego, skutkująca zasadą jednolitej własności środków finansowych, z włączeniem do budżetu państwa także budżetów rad narodowych oraz centralizmu demokratycznego, zakładająca priorytet decyzji centralnych, opartych na inicjatywach i konsultacjach szczebla lokalnego. Wiele podstawowych rozwiązań technicznych w obydwu systemach finansów lokalnych było podobnych, a wręcz identycznych. Nauka finansów publicznych w krajach socjalistycznych eksponowała jednak zagadnienia dochodów własnych rad narodowych, lokalnej samodzielności finansowej i decentralizacji, wręcz je fetyszyzując, gdy w krajach kapitalistycznych poświęcano tym kwestiom znacznie mniej uwagi. Można to tłumaczyć zagrożeniami, jakie zasady ustrojowe państw socjalistycznych niosły dla władzy lokalnej i finansów lokalnych, co nie występowało w państwach kapitalistycznych (Wilk i Łyszczak, 2004; Ruśkowski i Dolnicki, 2007).

Jeśli chodzi o formę państwa, to współcześni konstytucjonaliści wyróżniają w tym zakresie dwie zasadnicze formy: państwa unitarne oraz państwa federacyjne oraz formę pośrednią - państwa $\mathrm{z}$ konstytucyjną zasadą autonomii regionalnej. Czasami uznaje się państwo federacyjne za możliwy rezultat decentralizacji państwa unitarnego, zaś regionalizację państwa unitarnego za etap przejściowy do federacji. Ze swej istoty budowa państwa federalnego oraz struktura i kompetencje jego władz są odmienne niż w państwie unitarnym. W konsekwencji także charakter i struktura finansów lokalnych w tych państwach są zróżnicowane. Dlatego na podstawie kryterium formy państwa wyróżnia się trzy 
systemy finansów lokalnych (Kociubiński, 2008):

- finanse lokalne państw federalnych (np. USA, Kanada, Belgia, Niemcy),

- finanse lokalne państw unitarnych, które dotyczą przeważającej liczby współczesnych państw,

- finanse lokalne krajów z konstytucyjną zasadą autonomii regionalnej (Włochy, Hiszpania).

Różnice dotyczą głównie zakresu finansów lokalnych oraz autonomii finansowej władz lokalnych (traktowanych jako całość) wobec władz centralnych (rządowych) (Weaver i Longoria, 2002; Kulesza, 2000) W państwach federalnych musi występować podział terytorialny na kraje bądź ich odpowiedniki, zaś w państwach z konstytucyjna zasadą autonomii regionalnej - podzial na autonomiczne regiony. $\mathrm{Z}$ kolei w państwach unitarnych, ze względu na ich istotę, podziały te występować nie mogą. Niemniej jednak, we wszystkich formach współczesnych państw wystepuje od 1 do 3 szczebli podziału terytorialnego, co daje podstawę do wyróżnienia państw z:

- jednoszczeblową,

- dwuszczeblową,

- trójszczeblowa,

strukturą podziału terytorialnego (KosekWojnar i Surówka, 2002; Gilowska Płoskonka, Prutis, Stec i Wysocka, 1997).

Niektórzy autorzy wyróżniają (Stępień, 2006; Guziejewska, 2005):

- system północny jedno- albo dwuszczeblowy, np.:

- w państwach unitarnych: Szwecji, Danii, Finlandii, Wielkiej Brytanii, Holandii, Irlandii;

- w państwach federalnych: Niemczech, Belgii, Austrii;

- system łaciński z trzema szczeblami, np. we Włoszech, Hiszpanii, Francji, Polsce;

- system kontynentalny (nietypowy), np. w USA, Japonii.

$\mathrm{Z}$ reguły strukturze tej towarzyszy adekwatna struktura samorządu terytorialnego, a tej z kolei odpowiednia struktura finansów lokalnych. Wielość szczebli podziału terytorialnego sprzyja rozszerzaniu zakresu finansów lokalnych i decentralizacji finansów publicznych (Ruśkowski, 1997).

Według kryterium zakresu i jakości decentralizacji finansów publicznych (lokalnego władztwa podatkowego) wyróżnia się natomiast trzy systemy finansów lokalnych (Ruśkowski, 1997; Blanc, 2002):
- oparte na znacznej decentralizacji źródeł dochodów, np. Szwecji i Danii,

- oparte na znacznej centralizacji tych źródeł, np. we Francji, Wielkiej Brytanii czy Holandii,

- pośrednie, np. w Niemczech.

Szersza i bardziej pogłębiona analiza tego zagadnienia pozwala wyróżnić trzy systemy finansowania jednostek lokalnych:

- skandynawski (Szwecja, Dania, Finlandia), gdzie podatki lokalne reprezentuja 20-50\% wszystkich podatków i od 10 do $20 \% \mathrm{PKB}$

- łaciński (Włochy, Francja, Hiszpania), w którym wielkość podatków lokalnych stanowi około $20 \%$ wszystkich podatków i waha sie od 4 do $6 \%$ PKB;

- hanowerski (Niemcy, Wielka Brytania, Holandia, Polska), w którym podatki lokalne stanowią 4-5\% wszystkich podatków i reprezentują 1-2\% PKB.

\section{Samorząd terytorialny w Polsce}

Samorząd terytorialny ma w Polsce długą tradycję. Funkcjonował on od połowy XIV w. - już w tamtych czasach funkcjonowały struktury administracji samorzadowej i utrwalały się pierwsze wartości. Były one $\mathrm{z}$ biegiem lat wiele razy modyfikowane (Tucholska, 2007).

Czasy przedrozbiorowe i rozbiorowe wywarły piętno, które skutkuje do dziś wysokim poziomem rozwoju lub zapóźnieniem gospodarczym i cywilizacyjnym (Tucholska, 2007). Zarówno zaborca austriacki, jak i pruski wnosili duże nakłady finansowe w rozwój podległych im obszarów. Natomiast zaborca rosyjski wyzyskiwał i zubażał zależne od niego tereny.

W okresie miedzywojennym rozpoczeto ujednolicanie struktur samorządowych. Proces ten przerwała II wojna światowa (Leoński, 2006).

Po II wojnie światowej Polska wykazywała szczególnie duże przywiązanie do własnych, przedwojennych tradycji. Polska Ludowa była zmuszona była jednak do coraz rozleglejszej recepcji legislacji radzieckich (Izdebski, 2006).

W roku 1950 roku zniesione zostały urzędy starostów, których kompetencje przejęły rady powiatowe ${ }^{5}$. W roku 1975 powiaty zniknęly z polskiej mapy administracyjnej6 $^{6}$, a pojawiło się 49 województw.

Od roku 1990 zadaniowa luke po powiatach przejęly urzędy rejonowe, które peł- 
niły funkcję wyspecjalizowanych ogniw administracji rządowej. Wykonywały one określone w ustawach zadania i kompetencje organów terenowych ${ }^{7}$.

Ostatnie dwie dekady dwudziestego wieku były okresem znaczącej transformacji w zakresie lokalnej demokracji w całym rozwijającym się świecie - transformacji połączonej z decentralizacją, tzn. z przemieszczeniem władztwa politycznego, gospodarczego i administracyjnego na rzecz samorządów lokalnych (Bardhan i Mookherjee, 2006). W roku 1989 Polska rozpoczęła zasadniczą przebudowę swego ustroju i gospodarki w kierunku demokratycznego ustroju i gospodarki rynkowej (Szewc, 2010; Piotrowska-Marczak, 1997). W latach 1990-1998 prowadzono prace nad zmianą układu administracyjno-terytorialnego i kompetencyjno-zadaniowego (Słobodzian, 2005). Ich zwieńczeniem są klauzule dotyczące samorządu przejęte z Europejskiej Karty Rozwoju Lokalnego ${ }^{8}$, a zawarte w Konstytucji Rzeczypospolitej Polskiej z dnia 2 kwietnia 1997 roku $^{9}$.

Obowiązujące od tego czasu rozwiązanie to system (Kisiel, 2003; Miemiec, 1997):

- trójstopniowy ${ }^{10}$

- dualistyczny, a więc samorząd realizuje zarówno własne zadania, jak i zadania zlecone.

Na mocy ustawy o wprowadzeniu zasadniczego trójstopniowego podziału terytorialnego państwa ${ }^{11}$ oraz ustawy o samorządzie powiatowym ${ }^{12}$ od 1999 roku zadania publiczne o charakterze ponadgminnym przekazano powiatom. Przyjeto przy tym zasadę, że zadania powiatu nie mogą naruszać zakresu działania gmin. Powiat może na uzasadniony wniosek zainteresowanej gminy przekazywać jej jednak zadania leżące w jego kompetencji na warunkach porozumienia (Gorzelak i Jałowiecki, 2001; Emilewicz i Wolek, 2000; Gilowska, 1999).

Konstrukcja powiatu nie spełnia wymagań nowoczesnej administracji publicznej, zbliżającej się do prywatnej administracji biznesu, w której jednym z najważniejszych kierunków przemian jest wprowadzenie spłaszczonej i elastycznej struktury organizacyjnej, pozbawionej sztywnego podziału na zadania (Considine i Giguere, 2008; Piekara, 2003). Kwestionowanie istnienia średniego szczebla samorządu terytorialnego występuje również z innych przyczyn. Konstrukcja powiatu nie spełnia wymagań nowoczesnej administracji publicznej, która upodabnia się coraz bardziej do administracji prywatnego biznesu, elastycznej, mobilnej, pozbawionej sztywnego podziału zadań. W reformie powiatowej nie uwzględniono systemowego charakteru państwa, w którym różne elementy składowe powinny wzajemnie się dopełniać, tworząc możliwie harmonijną całość (Dylewski, Filipiak i Gorzałczyńska-Koczkodaj, 2004; Płoskonka, 2001).

Powiaty są przedmiotem uwag krytycznych, tym bardziej, że kolejne ekipy rządzące odbierają im kompetencje, pozbawiając je tym samym sensu istnienia. Dołączyły się do tego niewłaściwe mechanizmy doboru kadr urzęniczych w nowo tworzonych powiatach (Gorzelak i Jałowiecki, 2001).

Co więcej, wraz z reformą samorządową w 1998 r. powiatom powierzone zostały: stacje sanitarno-epidemiologiczne, inspektoraty weterynarii, komendy straży pożarnej, komendy policji oraz inspektoraty nadzoru budowlanego, a nadzór nad nimi sprawowali starostowie. W kolejnych latach następował jednak w tym obszarze wyraźny proces recentralizacji; starostom odbierane były kolejno kompetencje nadzoru nad tymi służbami. Zwyciężyły interesy resortów, nieistotne okazały się koszty tworzenia nowych struktur administracyjnych (Regulski, 2005).

Wielki uszczerbek w kompetencjach powiatów spowodowała reforma służby zdrowia, głównie ze względu na centralizacje finansowania placówek służby zdrowia, w tym również tych, których formalnym właścicielem nadal są powiaty. Decyzja o wprowadzeniu tak dużej liczby powiatów majacych do dyspozycji dochody niezadowalające i niegwarantujące należytej samodzielności zasadniczo nie satysfakcjonowała żadnej siły politycznej, jednak - w wymiarach lokalnych - zaspokajała ambicje społeczności lokalnych. Zamiary skorygowania ułomnej reformy przyświecały kolejnym rządom na etapie opracowywania założeń politycznych na kadencję, jednak rzadzacy tracili zapał, gdy próbowali zaplanować konkretne likwidacje powiatów zbyt małych albo niewydolnych finansowo (Rusek, 2008).

Powołanie powiatów jako korporacji ponadgminnych miało na celu stworzenie struktur dla rozwiązywania spraw, których podstawowa jednostka samorządu, czyli gmina, samodzielnie nie byłaby w stanie załatwić. Powiaty powinny więc uzupełniać 
działalność gmin w zakresie usług publicznych o charakterze ponadgminnym. Zaspokajanie społecznych potrzeb w ramach obu struktur ma się odbywać na zasadzie komplementarności. Relacje między powiatem a gminą oparte są na zasadzie pomocniczości, w myśl której gmina nie tylko jest jednostką podstawową, lecz także korzysta $\mathrm{z}$ prawa ustanowionej samodzielności i niezależności, a więc nie może być podporzadkowana powiatowi ani w zakresie osobowym, ani rzeczowym (Piekara, 2000; Filipiak i Szewczuk, 2009; Barański, 2009).

Powiaty nie sa jednak dostatecznie uzbrojone w mechanizmy wykonawcze. Dotyczy to zwłaszcza środków finansowych. Sytuacja finansowa polskich powiatów przedstawia się mianowicie tak, że znaczną ich cześś stanowia przyznawane rokrocznie dotacje celowe, a więc wydatki budżetu państwa na z góry określone cele na terenie poszczególnych powiatów ${ }^{13}$. Decyzja o tym, gdzie kierowane sa środki jednostek powiatowych, podejmowana jest zatem na szczeblu centralnym. W rezultacie powiaty nie mają siły finansowej, od której uzależniona jest absorpcja środków z funduszy unijnych czy też pozyskanie jakichkolwiek kredytów. W tej sytuacji powiaty nie sa w stanie kreować wydatków na cele interesu publicznego (Mańka, 2010).

Ponadto możliwości kompetencyjne i instytucjonalne powiatów są ograniczone i nieczytelne; brakuje funkcjonalnego określenia definicji powiatu. Samorząd drugiego szczebla stanowi jałowa nadbudowe przestrzeni gmin. Powiela niejednokrotnie te segmenty działań, z którymi i gminy wspólnie, albo pojedynczo by sobie doskonale poradziły. Powiaty osłabiaja skuteczność gmin, nie posiadają własnych ponadgminnych instrumentów działania. Ich rola sprowadza się właściwie do pasywnego administrowania, biernego zarzadzania zasobami rozmaitych dokumentów, dublowania działań gminy (Buchanan, 1991).

\section{Korekta kompetencji powiatów ziemskich}

Jedną z możliwych zmian w odniesieniu do powiatów ziemskich jest korekta ich kompetencji. Można jej dokonać na dwa sposoby, tzn. zmniejszając, lub zwiększając dotychczasowe kompetencje władz powiatów ziemskich.

\subsection{Rozwiązanie I: Zmniejszenie kompetencji powiatów ziemskich}

Zmniejszenie kompetencji władz powiatów ziemskich mogłoby polegać na zastapieniu dotychczasowych radnych powiatowych przedstawicielami organów gmin mieszczących się na terenie danego powiatu.

Uszczuplenie roli szczebla powiatowego poprawiłoby ogólne wyniki finansowe samorządów i usprawniło ich działanie. Relacje między powiatem i gminami mogłyby przybrać właściwy kształt, gdyby organ stanowiacy powiatu (rada) składał sie, na wzór systemu samorządowego w Niemczech, z wójtów, burmistrzów i prezydentów miast wchodzących w skład powiatu i przypominałby rejon administracyjny z lat 1990-1998. Wprowadzenie tego rozwiązania wpłynęłoby korzystnie na poziom samodzielności władz powiatowych, jednak musiałoby zostać poprzedzone korektą formuły ustawowej powiatów. Wysuwane sa przy tym różne propozycje dotyczące pozycji, jaka powinien zajmować powiat (Brol, 2012). Włączenie wójtów, burmistrzów i prezydentów miast do organu stanowiącego i kontrolnego powiatu wymusiłoby zarówno współprace gmin z powiatem, jak i współpracę między gminami wchodzącymi w skład powiatu. Współdziałanie wszystkich jednostek samorządowych w ramach powiatu byłoby bez wątpienia bardzo korzystne. Stałoby się to impulsem do tworzenia się local governance, tj. lokalnych wspólnot samorządowych, angażujących poszczególne podmioty $\mathrm{z}$ danego terytorium (Ostrom, 2008). Do myślenia w kategoriach interesu własnej gminy doszłaby szersza perspektywa planowania działań z poziomu subregionalnego. Można założyć, że włączenie się przedstawicieli gmin w zarządzanie powiatem poprawiłoby efektywność finansów powiatowych i pozwolitoby zwiększyć dochody z majątku powiatu, zwiększyć dochody na cele inwestycyjne oraz zredukować wydatki bieżące powiatu.

Współpraca między gminami nie jest jednak naturalnym działaniem wójtów, burmistrzów i prezydentów miast zorientowanych na swoje społeczności. Sa jednak potrzeby, których gminy nie zaspokoją we własnym zakresie. Według zasady pomocniczości powinien to czynić powiat, zgodnie $\mathrm{z}$ interesami gmin wchodzacych $\mathrm{w}$ jego skład. Członkowie organu stanowiącego i kontrolnego w powiecie mieliby odpo- 
wiednią, silną legitymację od swoich wyborców na podstawie wyborów bezpośrednich. Współpraca wójtów w strukturze ponadgminnej, nawet gdyby wiązała się z określonymi konfliktami, byłaby bardziej czytelna dla mieszkańców powiatu niż niezrozumiałe dla przeciętnego mieszkańca i niemające odniesienia do lokalnych realiów polityczne potyczki partyjnych radnych. Ograniczenie procedur demokratycznych ze względu na eliminację wyborów do średniego szczebla mogłoby wpłynąć na procesy utożsamiania się i integracji społeczności na poziomie subregionów. Wydaje się również, że finansowe, kompetencyjne i władcze wzmocnienie powiatu w żadnej mierze nie zaszkodziłoby gminom, a wręcz usunęłoby antagonizm pomiędzy tymi szczeblami samorządów, wywołując efekt synergii (Kulesza, 2005).

Uszczuplenie roli szczebla powiatowego wymagałoby nowelizacji Ustawy o dochodach jednostek samorządu terytorialnego i wprowadzenia do niej stosownych zapisów. Podobnie rzecz się ma, jeśli chodzi o inne akty prawne regulujące funkcjonowanie powiatów. Proces reformowania zająłby więc kilka lat. Rezultaty, jakie przyniosłaby korekta kompetencji powiatów związana $\mathrm{z}$ wprowadzeniem wójtów, burmistrzów i prezydentów miast wchodzących w skład powiatu do jego władz, zaprezentowane sa na rysunku 1.

Generalnie widoczna jest na nim poprawa wyników, zarówno w obszarze dochodów budżetowych, jak i w obszarze wydatków budżetowych. Na rysunku 1 zaprezentowano też poważną przeszkodę we wprowadzeniu tego rozwiazania. Składa się na nią konieczność nowelizacji wszystkich aktów prawnych - począwszy od Ustawy o finansach publicznych, poprzez Ustawę o dochodach jednostek samorządu terytorialnego, a na Ustawie o samorządzie powiatowym skończywszy. Jako że rozwiązanie to wymagałoby korekty funkcjonowania gmin, niezbędna byłaby również nowelizacja Ustawy o samorządzie gminnym. Wymienione ustawy to tylko najważniejsze $\mathrm{z}$ aktów prawnych, które należałoby zmienić. Wprowadzenie tego rozwiązania byłoby więc bardzo oddalone w czasie.

Niemniej jednak z powyższej korekty płynęłyby same pozytywne skutki. Przede wszystkim w obszarze dochodów budżetowych, w którym wyraźnie zwiększyłaby się wartość udziału dochodów własnych w dochodach budżetu ogółem, przy jednoczesnym spadku wartości udziału, zarówno subwencji ogólnej, jak i dotacji celowych, w dochodach budżetu ogółem. Zwiększyłaby sie samodzielność władz powiatów ziemskich w zakresie podejmowania decyzji oraz siła do pozyskiwania środków zewnętrznych, również poprzez zdolność do emisji komunalnych papierów wartościowych.

Korzystne zmiany w obszarze dochodów budżetowych przełożyły się na pozytywną tendencję w relacji dochodów ogółem oraz wydatków ogółem. W obszarze wydatków ogółem nastąpiłby wyraźny spadek wartości udziału wydatków bieżących w wydatkach ogółem, przy jednoczesnym wzroście wartości udziału wydatków majątkowych w wydatkach ogółem. Wiązałoby sie to z bardziej trafnym planem wydatków, rosnącą płynnością finansową, wynikiem operacyjnym oraz wydatkami na inwestycje.

Obciążone historycznie powiaty województw wschodnich naszego kraju miałyby większą szansę na niwelowanie różnic $\mathrm{w}$ ich potencjale $\mathrm{w}$ porównaniu $\mathrm{z}$ powiatami takich województw jak mazowieckie, wielkopolskie, czy śląskie, które obecnie są liderami rankingów opartych na charakterystykach społeczno-gospodarczych. Mocne powiaty miałyby jednocześnie szansę na jeszcze szybszy rozwój. $\mathrm{Na}$ znaczeniu mógłby zyskać potencjał geopolityczny i związana z nim unikatowa specyfika każdego powiatu ziemskiego.

\subsection{Rozwiązanie II: Zwiększenie kompetencji powiatów ziemskich}

Drugim możliwym kierunkiem zmian dotyczącym kompetencji powiatów jest ich zwiększenie. Można by tego dokonać poprzez rozszerzenie kompetencji o elementy znajdujące się obecnie w gestii administracji rządowej, zwiększenie udziału powiatów ziemskich w podatkach dochodowych, lub też umocowanie w prawie podatków lokalnych ustalanych co do wysokości przez władze danego powiatu płaconych na rzecz tego powiatu.

Zasilanie budżetów powiatowych oparte na podatkach lokalnych pozwoliłoby na wzrost samodzielności i odpowiedzialności za ogół lokalnych zadań (Hadrowicz, 2010). Powiaty ziemskie mogłyby zbliżyć się w osiagganych rezultatach do miast na prawach powiatu czy gmin. Obie te struktury samorządowe są zaopatrzone w dużo bogat- 
szy wachlarz dochodów własnych - dużą ich część samodzielnie stanowią, co przynosi wymierne skutki i bardzie optymistycznymi czyni prognozy przyszłych wartości.

Możliwość ta wydaje się jednak czysto teoretyczna, ponieważ skoro rząd dosyć często wprowadzał rozwiązania, które zmniejszały budżety lokalne, a nie rekompensowal strat tym spowodowanych, nie wydaje się możliwa sytuacja odwrotna. Ilekroć podejmowana jest inicjatywa w tej sprawie, przepada ona na etapie prac rządowych, będąc oceniana jako zbyt droga dla budżetu państwa (Jęczmionka, 2012).

Elity lokalne oczekują zwiększenia wpływów i poszerzenia swobody wydatkowania środków (Wyganowski, 2007). Wdrożenie tego rozwiązania oznaczałoby zerwanie $\mathrm{z}$ centralnym sterowaniem finansami powiatów ziemskich i włożenie ich włodarzom w ręce narzędzi do kreowania samodzielności i faktycznej samorządności, niezawisłości. Powiaty cieszyłyby się wyraźnie wyższymi dochodami własnymi, choć trzeba pamiętać, że dochody te są związane głównie $\mathrm{z}$ udziałem jednostek powiatowych $\mathrm{w}$ dochodach $\mathrm{z}$ podatków dochodowych, w głównej mierze uzależnionych od zasobności mieszkańców powiatów i przedsiębiorstw mieszczących się na ich terenie. Większe kompetencje władz samorządowych mogłyby jednak i w tym względzie przynieść wymierne skutki, choćby ze względu na bardziej trafny plan wydatków budżetowych.

Rezultaty, jakie przyniosłaby korekta kompetencji powiatów związana ze zwiększeniem tych kompetencji, zaprezentowane są na rysunku 2. Pokazana jest na nim podobna co do charakteru, ale jeszcze korzystniejsza niż we wcześniejszym rozwiązaniu poprawa wyników, zarówno w obszarze dochodów budżetowych, jak i w obszarze wydatków budżetowych.

\section{Podsumowanie}

Współczesne nowe wyzwania zmuszają do przewartościowania spojrzenia na kwestię samorządności. Współczesna rzeczywistość społeczno-polityczna na tyle odmieniła swoje oblicze, że konieczne jest zastanowienie się, czy zastosowana zostaje najbardziej dla niej adekwatna forma samorządu terytorialnego. Globalizacja, spadek partycypacji społecznej w sprawo- waniu lokalnej władzy i w wyborach oraz zmniejszająca się legitymizacja rządów i samorządów to realne wyzwania, z którymi mierzą się politycy i aktywiści na co dzień - zarówno w Polsce, jak i w całej Europie.

Współczesne społeczeństwa - każde na swój sposób - dążą do efektywności wszystkich elementów wchodzących w skład systemu społecznego. Perspektywę rozwoju tego układu określa system władzy. Dla interesu publicznego najważniejszą rolę odgrywa stworzenie warunków dla inicjatyw społecznych, u podłoża których leżą postawy kreatywne. Wyzwoleniu zachowań tego rodzaju sprzyjają okoliczności w takiej organizacji ładu społecznego, którą określa się w socjologii mianem lokalizmu. Oznacza to koncentrację życia społecznego i gospodarczego w społecznościach lokalnych i prymat stosunków tam wytworzonych nad stosunkami na szczeblu społeczeństwa globalnego.

Obecnie od samorządu lokalnego oczekuje się, że będzie on siłą motoryczną rozwoju lokalnego, który - przy możliwie najszerszej reprezentacji interesu lokalnej społeczności - kreuje i utrzymuje w rozwoju kompleks walorów użytkowych i sił wytwórczych układu lokalnego. Zreformowany samorząd terytorialny powinien tworzyć regiony jako podmioty polityki regionalnej. Jednocześnie regiony powinny być zgodne $\mathrm{z}$ tradycjami historycznymi, uwarunkowaniami geograficznymi, politycznymi, prawnymi, społecznymi, gospodarczymi i finansowymi, a przede wszystkim, oczekiwaniami wspólnot terytorialnych. Równolegle, celem reformy powinna być budowa państwa, zdefiniowanego jako instytucja pomocnicza, które zapewniałoby zdolność poszczególnych regionów do długofalowego rozwoju prowadzącego do konwergencji z regionami Unii Europejskiej (Błaszczuk i Stefański, 2010). Szczególna uwaga powinna być poświęcona tworzeniu jak najlepszych warunków rozwoju gospodarki i wzrostu zamożności mieszkańców regionów oraz wszechstronnej poprawy warunków życia ich społeczeństw. A zatem chodzi nie tylko o możliwość utrzymania wysokiego tempa rozwoju gospodarczego, lecz również o równoczesne wprowadzenie instytucji ustrojowych, stabilizujących państwo jako strukturę społeczną, polityczną i ekonomiczną. 
Na konieczność zmian w strukturze polskich samorządów wskazuje również diagnoza przedstawiająca obecną sytuację powiatów ziemskich. Powodem tego jest po pierwsze, ich niewielki obszar o niewielkiej populacji, po drugie słaba sytuacja finansowa.

Ponadto powiaty są coraz mniej zaopatrzone w prawne atrybuty samorządności i mają coraz mniejszy wpływ na środowisko lokalne.

Prognoza funkcjonowania powiatów ziemskich wskazuje, że korekta systemu samorządowego jest niezbędna. Tym bardziej, że - póki co - legislacja stanowiąca o wydatkach polskich powiatów ziemskich utrwala nieprawidłowości w funkcjonowaniu tych jednostek.

Dobrym rozwiązaniem są związki między powiatami czy też związki powiatów i rzeczywiście samodzielnych gmin. Rozwiązanie to jest popierane i aktualnie inicjowane przez Ministerstwo Automatyzacji i Cyfryzacji, a w literaturze przedstawione przez laureatkę Nagrody Nobla Elinor Ostrom (Ostrom, 2008). Wydaje się ono drogą do pojawienia się w Polsce prawdziwych wspólnot samorządnych.

Równie ciekawym rozwiązaniem problemu wydaje się zmiana kompetencji samorządów powiatowych ziemskich polegająca na korekcie formuły ustawowej powiatów i przekazaniu im większych dochodów i większych kompetencji, z dopuszczeniem włodarzy gminnych do głosu na poziomie jednostki powiatowej ziemskiej. Taka formuła jest $\mathrm{z}$ powodzeniem realizowana przez powiaty grodzkie.

\section{Przypisy}

1 Treści i wnioski zawarte w niniejszym artykule są oparte za badaniach stanowiących część rozprawy doktorskiej Koza (2013).

2 Jednym $z$ nich jest analiza strumieniowa - strategiczna metoda diagnozowania i wizualizacji trudności oraz kierowania zmianami w organizacjach; szerzej: Porras (1987).

3 Szerzej: Konstytucja Francji. Wydawnictwo 2 uaktualnione (2005).

4 Wiele przykładów przytacza: Local government in transition countries: a perspective for the year 2000 (1996, s. 1-12).

5 Na mocy Ustawy z 20 marca 1950 roku o terenowych organach jednolitej władzy państwowej, Dz.U. 1950 nr 14 poz. 130.
6 Na mocy Ustawy z 28 maja 1975 roku o dwustopniowym podziale administracyjnym państwa, Dz.U. 1975 nr 16 poz. 91.

7 Na mocy Ustawy z 22 marca 1990 roku o terenowych organach rządowej administracji ogólnej, Dz.U. 1990 nr 21 poz. 123.

8 Europejska Karta Samorządu Terytorialnego, Dz.U.1994.124.607 z późn. zm.

9 Konstytucja Rzeczypospolitej Polskiej z dnia 2 kwietnia 1997 roku, Dz. U. z 1997 roku, nr 78, poz. 483.

10 Ustawa z dnia 17 maja 1990 r. o podziale zadań i kompetencji pomiędzy organy administracji rządowej i samorządowej, Dz. U. nr 34, poz. 198 z 1990 r. z późn. zm. oraz Ustawa z dnia 24 lipca 1998 r. o zmianie niektórych ustaw określających kompetencje organów administracji publicznej, Dz. U. nr 106, poz. 668, z 1998 r. z późn. zm.

11 Ustawa z dnia 24 lipca 1998 roku o wprowadzeniu zasadniczego trójstopniowego podziału terytorialnego państwa, Dz.U. z 1998 roku nr 96, poz. $603 \mathrm{z}$ późn. zm.

12 Ustawa z dnia 5 czerwca 1998 roku o samorzadzie powiatowym, Dz.U. 1998 nr 91 poz. 578 z późn. zm.

13 Dz. U. z 2003 Nr 203 poz. 1966 z późn. zm.

\section{Bibliografia}

Appuhn, K. i Warde, P. (2008). Ecology, Economy and State Formation in Early Modern Germany. Comparative Studies in Society and History, 50(2).

Barański, M. (2009). Samorzad terytorialny w Europie Środkowej $i$ Wschodniej. Katowice: Wydawnictwo Adam Marszałek.

Bardhan, P. i Mookherjee, D. (2006). Decentralization and local governance in developing countries. Cambridge: The MIT Press Cambridge.

Blanc, J. (2002). Finances locales comparées. Paris. Brol, R. (2012). Układ terytorialny powiatów propozycje zmian. Prace Naukowe Uniwersytetu Ekonomicznego we Wroctawiu, 243.

Błaszczuk, D.J. i Stefański, M. (red.). (2010). Strategiczna problematyka rozwoju Polski Wschodniej. Lublin: Wyższa Szkoła Ekonomii i Innowacji w Lublinie.

Buchanan, J.M. (1991). Economics in the postsocialist century. Economic Journal, 404.

Considine, M. i Giguere, S. (red.). (2008). The theory and practice of local governance and economic development. New York: Palgrave Macmillan, http:// dx.doi.org/10.1057/9780230582682

Dolnicki, B. (2003). Samorząd terytorialny. Kraków: Wydawnictwo Zakamycze.

Dylewski, M., Filipiak, B. i Gorzałczyńska-Koczkodaj, M. (2004). Analiza finansowa w jednostkach samorzadu terytorialnego. Warszawa: Municipium. 
Rysunek 1. Rozwiązanie I: Korekta kompetencji powiatów ziemskich - zmniejszenie kompetencji powiatów

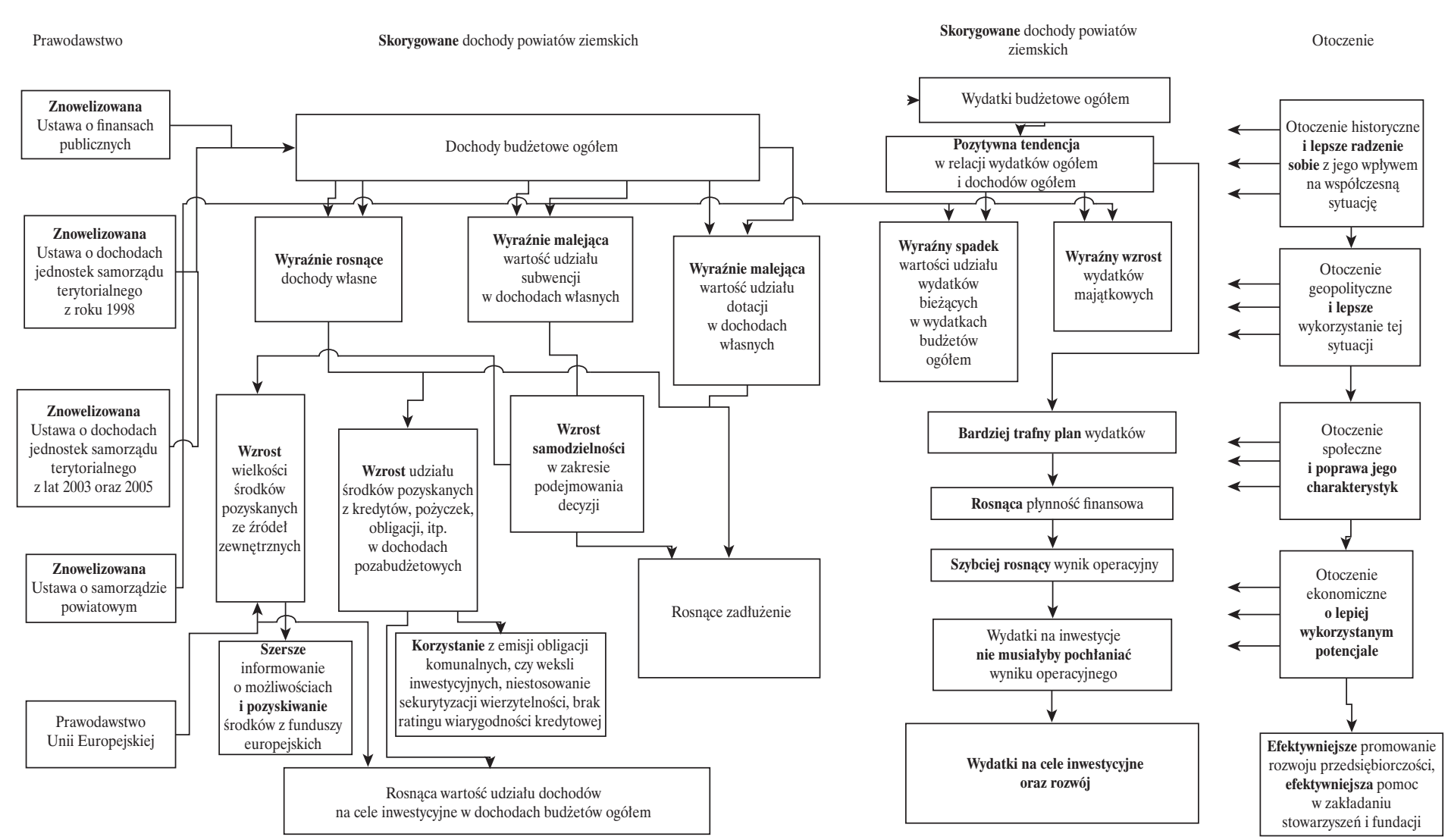


Rysunek 2. Rozwiązanie II: Korekta kompetencji powiatów ziemskich - zwiększenie kompetencji powiatów

Prawodawstwo
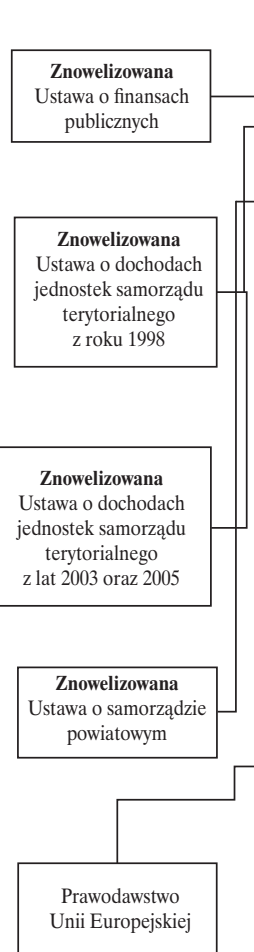

Skorygowane dochody powiatów ziemskich

$$
\begin{aligned}
& \text { wane dochody } \\
& \text { ziemskich }
\end{aligned}
$$

$\longrightarrow$ Wydatki budżetowe ogófem
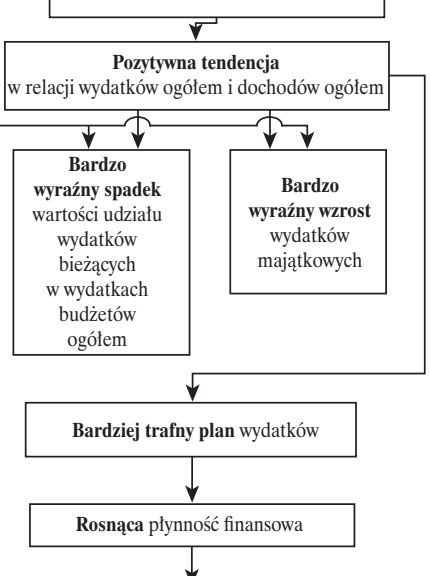

Szybciej rosnący wynik operacyjny

Rosnące zadłużenie

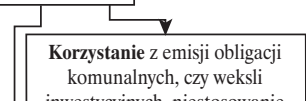
komunalnych, czy weksli
inwestycynych, niestosowanie sekurytyzacji wierzytelności, brak
ratingu wiarygodności kredytowej możliwościach pozyskiwanie
dków $z$ fundusz europejskich

\section{$\checkmark$}

Rosnąca wartość udziału dochodów
na cele inwestycyjne w dochodach budżetów ogólem

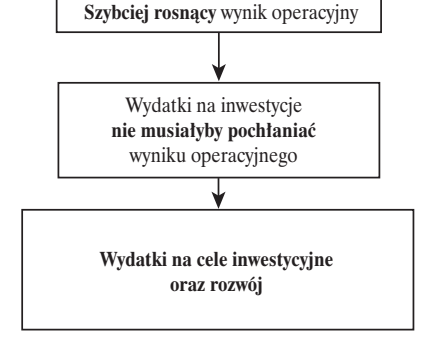

Otoczenie

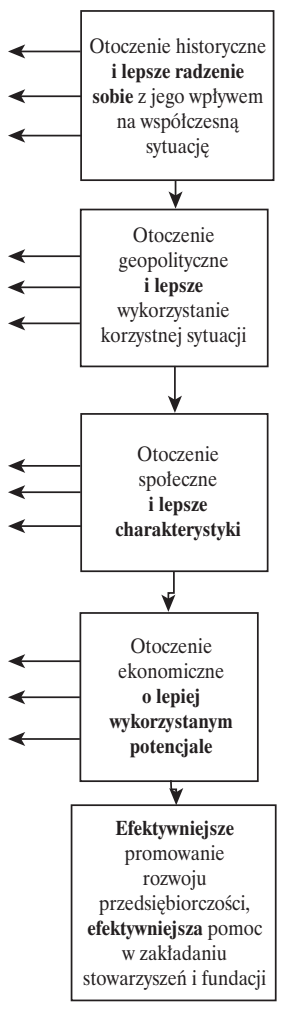

Źródło: opracowanie własne. 
Dylewski, M., Filipiak, B. i Gorzałczyńska-Koczkodaj, M. (2006). Finanse samorzadowe. Warszawa: WN PWN.

Emilewicz, J. i Wolek, A. (2000). Reformatorzy i politycy. Gra o reforme ustrojowa roku 1998 widziana oczami jej aktorów. Warszawa: FRDL.

Europejska Karta Samorządu Terytorialnego, Dz.U.1994.124.607 z późn. zm.

Filipiak, B. i Szewczuk, A. (red.). (2009). Samorzad terytorialny w zintegrowanej Europie. Szczecin Wydawnictwo Naukowe Uniwersytetu Szczecińskiego.

Gajl, N. (1993). Finanse i gospodarka lokalna na świecie. Warszawa: PWE.

Gilowska, Z. (1999). Finansowanie samorządu terytorialnego według ustaw o finansach publicznych oraz o dochodach jednostek samorządu terytorialnego. Samorzad Terytorialny, 3.

Gilowska, Z., Płoskonka, J., Prutis, S., Stec, M. i Wysocka, E. (1997). Model ustrojowy województwa (regionu) w unitarnym państwie demokratycznym. Samorzad Terytorialny, 8-9.

Gorzelak, G. i Jałowiecki, B. (2001). Reforma terytorialnej organizacji kraju: dwa lata doświadczen. Warszawa: Wydawnictwo Naukowe Scholar.

Gremion, C. (2002). Local Government Development in France. Japanese Journal of Political Science, 3(1)

Guziejewska, B. (2005). Koncepcje samorządu terytorialnego a źródła jego finansowania. Samorząd Terytorialny, 5 .

Guziejewska, B. (2000). Perspektywy funkcjonowania samorządu terytorialnego a doświadczenia Wielkiej Brytanii. Samorzad Terytorialny, 9.

Hadrowicz, E. (2010). Reprezentacja powiatu czyżby instytucja wymagająca zmian. Samorzad Terytorialny, 10.

Izdebski, H. (2006). Samorzad terytorialny: podstawy ustroju $i$ działalności. Warszawa: Wydawnictwo Prawnicze LexisNexis.

Jęczmionka, P., Rzad powiatom odbiera, o likwidacji głośno nie mówi. Pozyskano z: http://www.gloswielkopolski.pl/artykul/548631,rzad-powiatom-odbierao-likwidacji-glosno-nie-mowi,id,t.html (12.04.2012).

Kaczmarek, T. (2005). Struktury terytorialno-administracyjne $i$ ich reformy $w$ krajach europejskich Poznań: Wydawnictwo Naukowe Uniwersytetu im. Adama Mickiewicza.

Kasiński, M. (2008). Samorząd terytorialny jako wartość cywilizacyjna. Annales. Etyka w życiu gospodarczym, 11(2).

Kisiel, W. (2003). Ustrój samorzadu terytorialnego w Polsce. Warszawa: Wydawnictwo Naukowe PWN.

Kleer, J. (2008). Sektor publiczny w warunkach współczesnych. Optimum. Studia Ekonomiczne, 4.
Kociubiński, K. (red.). (2008). Samorzad terytorialny w Europie i Polsce: wybrane aspekty. Toruń: Wydawnictwo Adam Marszałek.

Konstytucja Francji. Wydawnictwo 2 uaktualnione (2005). tłum. Wiesław Skrzydło. Warszawa: Wydawnictwo Sejmowe.

Konstytucja Rzeczypospolitej Polskiej z dnia 2 kwietnia 1997 roku, Dz. U. z 1997 roku, nr 78, poz. 483.

Kosek-Wojnar, M. i Surówka, K. (2002). Finanse samorzadu terytorialnego. Kraków: Wydawnictwo AE w Krakowie.

Koza, I. (2013). Aspekty ekonomiczne funkcjonowania powiatów ziemskich $w$ Polsce, niepublikowana rozprawa doktorska. Warszawa: Instytut Zarzadzania Ryzykiem Akademii Finansów i Biznesu Vistula.

Kulesza, M. (2005). Konsolidacja zarządzania. Wspólnota, 23.

Kulesza, M. (2000). Rozwój regionalny. Zagadnienia instytucjonalne. Samorzad Terytorialny, 10.

Leoński, Z. (2006). Samorzad Terytorialny w RP. Warszawa: Lexis Nexis.

Local government in transition countries: a perspective for the year 2000 (1996). Intern. City/County Management Association, Sofia.

Łokucijewski, K. (1998). Angielski model demokracji lokalnej i jego praktyczne uwarunkowania Samorzad Terytorialny, 3.

MacGregor, Burns J. (1979). Leadership. New YorkSan Francisco-London: Harper Colophon Books.

Maciejewski, T. (2006). Historia administracji. Warszawa: C.H. Beck.

Mańka, R. (2010). Samorzad to przede wszystkim ludzie, www.gazetafinansowa.pl (05.11.2012).

Miemiec, W. (1997). Finanse samorządu terytorialnego w Konstytucji Rzeczypospolitej Polskiej. Finanse Komunalne, 5.

Oates, W.E. (1999). An Essay on Fiscal Federlism. Journal of Economic Literature, XXXVII.

Ostrom, E. (2008). Governing the commons: the evolution of institutions for collective action. Cambridge, New York: Cambridge University Press.

Palmowski, J. (2002). Liberalism and local government in late nineteenth - century Germany and England. The Historical Journal, 45(02).

Piekara, A. (2003). Cele i skuteczność reformy administracji publicznej w latach 1998-2001. Warszawa: Uniwersytet Warszawski, Centrum Studiów Samorządu Terytorialnego i Rozwoju Lokalnego.

Piekara, A. (red.). (2003). Decentralizacja terytorialna administracji publicznej: funkcje i dysfunkcje. Warszawa: WPiAUW.

Piotrowska-Marczak, K. (1997). Finanse lokalne w Polsce. Warszawa: Wydawnictwo Naukowe PWN. 
Płoskonka, J. (2001). Reforma administracji publicznej 1998-2001. Warszawa: MSWiA.

Porras, J.I. (1987). Stream analysis. A powerful way to diagnose and manage organizational changes. Don Mills: Addison-Wesley.

Przedwojenny samorząd terytorialny podstawą odbudowy samorządu lokalnego z III Rzeczypospolitej (2003). Samorzad Terytorialny, 1-2.

Rajca, L. (2008). Demokracja lokalna i regionalna w państwach Europy Zachodniej. Samorząd Terytorialny, 6 .

Rajca, L. (2007). Reformy samorządu lokalnego w Anglii. Samorzad Terytorialny, 12.

Regulski, J. (2005). Samorzadna Polska. Warszawa Wydawnictwo Rosner i Wspólnicy.

Reprezentacja powiatu - czyżby instytucja wymagająca zmian (2010). Samorzad Terytorialny, 10.

Rusek, M. (2008). Powrót do powiatu radomskiego to absurd. Gazeta Wyborcza, 25 maja.

Ruśkowski, E. (red.). (1997). Finanse komunalne $w$ wybranych krajach europejskich. Białystok: Temida 2.

Ruśkowski, E. i Dolnicki, B. (red.). (2007). Wtadza $i$ finanse lokalne $w$ Polsce $i$ krajach ościennych. Bydgoszcz: Oficyna Wydawnicza Branta.

Sanford, T. (2004). Political Innovation. Electoral Systems and Revitalising Democracy, Local Government Studies, 1.

Słobodzian, B. (2005). Wspótczesny system samorzadu terytorialnego w Polsce. Toruń: Wydawnictwo Adam Marszałek.

Sochacka-Krysiak, H. (2001). Decentralizacja finansów publicznych a samodzielność finansowa jednostek samorzadu terytorialnego. Warszawa: PWE

Stępień, H. (2006). Finanse lokalne $w$ warunkach decentralizacji finansów publicznych. Włocławek: Wyższa Szkoła Humanistyczno-Ekonomiczna we Włocławku.

Stoker, G. (1988). The politics of local government. London: Macmillan.

Swianiewicz, P. (red.). (1997). Wartości podstawowe samorzadu terytorialnego i demokracji lokalnej. Warszawa: Municipium.
Szewc, A. (2010). Ewolucja polskiego prawa samorządu terytorialnego w latach 1990-2010. Samorzad Terytorialny, 5 .

Tucholska, A. (2007). Powiat - między zbiorowościq a wspólnota. Warszawa: Wydawnictwo Naukowe Scholar.

Turpin, C. (1986). Legitimacy and the Constitution. Essays Marking the Centenary of Law of the Constitution. The Cambridge Law Journal, 45(02).

Ustawa z 20 marca 1950 roku o terenowych organach jednolitej władzy państwowej, Dz.U. 1950 nr 14 poz. 130 .

Ustawa z 22 marca 1990 roku o terenowych organach rządowej administracji ogólnej, Dz.U. 1990 nr 21 poz. 123 .

Ustawa z 28 maja 1975 roku o dwustopniowym podziale administracyjnym państwa, Dz.U. 1975 nr 16 poz. 91

Ustawa z dnia 17 maja 1990 r. o podziale zadań i kompetencji pomiędzy organy administracji rządowej i samorządowej, Dz. U. nr 34, poz. 198 z 1990 r. z późn. $z m$.

Ustawa z dnia 24 lipca 1998 r. o zmianie niektórych ustaw określających kompetencje organów administracji publicznej, Dz. U. nr 106, poz. 668, z 1998 r. z późn. $z m$.

Ustawa z dnia 24 lipca 1998 roku o wprowadzeniu zasadniczego trójstopniowego podziału terytorialnego państwa, Dz.U. z 1998 roku nr 96, poz. 603 z późn. zm.

Ustawa z dnia 5 czerwca 1998 roku o samorządzie powiatowym, Dz.U. 1998 nr 91 poz. 578 z późn. zm.

Weaver, W.G. i Longoria, T. (2002). Bureaucracy that Kills: Federal Sovereign Immunity and the Discretionary Function Exception. American Political Science Review, 96(02).

Wilk, K. i Łyszczak M. (red.). (2004). Gospodarka przestrzeń - rozwój. Wrocław: Wydawnictwo Akad. Ekonomicznej im. Oskara Langego we Wrocławiu.

Wojnicki, J. (2003). Samorzad lokalny w Polsce i w Europie. Pułtusk: Wyższa Szkoła Humanistyczna im. Aleksandra Gieysztora w Pułtusku.

Wyganowski, J. (2007). Samowystarczalny powiat. Nowe Życie Gospodarcze, 1. 